\title{
ОПАНУВАННЯ СТУДЕНТАМИ ПРАКТИЧНИХ НАВИЧОК ЯК СКЛАДОВА ЧАСТИНА ПОКРАЩЕННЯ ЯКОСТІ НАВЧАЛЬНОГО ПРОЦЕСУ НА КАФЕДРІ НЕЙРОХІРУРГІЇ І НЕВРОЛОГІЇ ОДЕСЬКОГО ДЕРЖАВНОГО МЕДИЧНОГО УНІВЕРСИТЕТУ
}

\author{
А. С. Сон, В. В. Добровольський, Ю. І. Горанський, О. М. Стоянов, \\ Н. В. Добровольська
}

Одеський державний медичний університет

\section{STUDENTS PRACTICAL SKILLS MASTERY AS A PART OF IMPROVING THE QUALITY OF STUDY AT THE DEPARTMENT OF NEUROSURGERY AND NEUROLOGY OF ODESSA STATE MEDICAL UNIVERSITY}

\author{
A. S. Son, V. V. Dobrovolskyi, Yu.I. Horanskyi, O. M. Stoyanov, N. V. Dobrovolska \\ Odessa State Medical University
}

\begin{abstract}
У статті представлений аналіз методичних підходів, запропонованих кафедрою нейрохірургії і неврології Одеського державного медичного університету, щодо підвищення якості навчальної роботи, зокрема опанування практичних навичок.
\end{abstract}

The article presents an analysis of methodological approaches proposed by the Department of Neurosurgery and Neurology of Odessa State Medical University, to improve the quality of academic work, including mastery of practical skills.

Вступ. За останні роки в зв'язку з реформуванням медичної освіти, розвитком приватного підприємництва, масовим виїздом медичних працівників за кордон, підвищилось значення конкурентноздатності кожного лікаря. Більшість 3 випускників, зустрівшись 3 практичним виконанням своїх обов' язків, зустрічаються $з$ певними труднощами. Це пов'язано $з$ тим, що більшість 3 них працюють “у відриві” від великих медичних закладів і далеко не всі колеги мають бажання ділитися набутим досвідом.

Питання підвищення якості підготовки лікарів-неврологів і нейрохірургів у стінах медичного ВНЗ виходить на перший план. Особливо це стосується набуття практичних навичок роботи з пацієнтом. Розвиток сімейної медицини, де частіше за все молоді сімейні лікарі в стислий термін особистоповинніприймати рішення, від якого залежить якість лікування хворого, спонукає нас піднімати рівень практичної й теоретичної підготовки майбутніх лікарів.

Як відомо з педагогіки, навчання - це двобічний процес, i багато залежить не тільки від якості подачі інформації викладачами кафедри, але й від мотивації опанування матеріалу студентами. Як показує наш досвід, прикладом підвищеної мотивації, щодо навчан- ня на кафедрі, є у студентів-іноземців, особливо 3 таких країн, як Ізраїль, Індія тощо. Студенти з цих країн вже відчули тиск ринкової економіки та конкуренції за місце роботи, вимагають від викладача всебічної інформації та намагаються засвоїти якнайкраще практичні навички біля ліжка хворого. Під час складання модулів ці студенти розгортають боротьбу за кожний додатковий бал у загальній оцінці. Високий рейтинг (максимальна кількість балів) дозволить їм обирати в рідній країні нетільки спеціальність, але й місце майбутньої практики [1].

Саме тому на кафедрі приділено особливу увагу мотивації студентів до навчання та в першу чергу до практичної роботи з пацієнтом. Це дає можливість не тільки підвищити якість навчального процесу, майбутню конкурентноспроможність наших випускників, але й виявити, допомогти становленню студентів, які в майбутньому стануть фахівцями неврологами та нейрохірургами.

Така постановка питання вимагає нових підходів в організації навчально-лікувального процесу на кафедрі.

Основна частина. Йдучи назустріч побажанням студентам, найбільш зацікавленим в отриманні практичних навичок роботи з пацієнтом, на кафедрі ней-

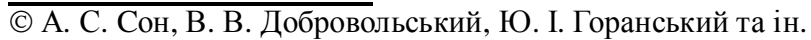


рохірургії і неврології створена система, яка удосконалює можливість набуття студентами практичних навичок, безпосередньо контактуючи 3 лікуючим лікарем і пацієнтом під час лікувального процесу, об' єднуючи його з навчальним.

1. Система направлена на підвищення знань та вмінь студентів як майбутніх фахівців. Для цього їм надана широка можливість роботи в електронній бібліотеці кафедри, де підібрані підручники, методичні посібники, медичні фільми, наукові оглядові статті 3 найскладніших тем 3 неврології та нейрохірургіï [2].

Для підвищення мотивації студентам рекомендовано для розгляду матеріали з історії розвитку національної української, світової та одеської шкіл неврології. В цьому плані студенти разом $з$ викладачем відвідують музей ОДМУ та Одеський дім вчених. На лекціях доводяться основні досягнення ОДМУ та одеської неврологічної школи.

2. Для студентів, які вирішили в майбутньому стати неврологами та нейрохірургами, мають намір вивчати неврологію більш детально, в тому числі й в позанавчальний час, для підвищення рівня практичних навичок сформований графік роботи в неврологічному відділенні в якості помічника чергового лікаря. За загальною домовленістю студенти працюють поруч з черговим лікарем і таким чином мають змогу дослідити всі аспекти спілкування з пацієнтом (збір скарг, обговорення анамнезу захворювання та життя), первинного огляду хворого, визначення ряду синдромологічної диференційної діагностики, планування діагностичних та лікувальних заходів. Після закінчення чергування відбувається обговорення та підведення підсумків викладачем-куратором. Опитування студентів підтверджують позитивне ставлення більшості студентів до такого заходу.

3. 3 ініціативи кафедри створене одеське наукове товариство неврологів, на засіданнях якого виступають найдосвідченіші фахівці з приводу складних клінічних випадків, актуальних тем діагностики та лікування захворювань нервової системи. Під час засідання наукового товариства використовуються матеріали електронної бібліотеки кафедри. Кількість студентів, які постійно, за особистим бажанням, відвідують засідання наукового товариства неврологів, за останні три роки прогресивно збільшується 32 (2007 р.), 8 (2008 р.) до 12 (2009 р.).

4. Студенти запрошуються на всі науково-практичні заходи, які проводяться співробітниками кафедри (конференціі, семінари тощо), де обговорюються не тільки теоретичні, а й практичні питання, що дає мож- ливість студентам бути інформованими в нових тенденціях розвитку сучасної медичної думки, зокрема неврологіі.

5. Під час практичних занять, при клінічному розборі теми зі спеціальної неврології безпосередньо в палаті біля ліжка хворого, студенти особисто беруть участь в проведенні діагностичних, інколи лікувальних маніпуляцій, вивчають на практиці нюанси поводження лікаря, медичної сестри, пацієнта. Через уміло організований навчальний процес студенти знаходять своє місце в складнощах діагностично-лікувального процесу, що позитивно впливає на їх світогляд, допомагає їм визначитись зі своєю майбутньою спеціалізацією.

Враховуючи результати опитування серед студентів четвертого курсу в 2008/2009 навчальних роках, на етапах початку проходження курсу нервових хвороб та після складення останнього модуля, ми дійшли висновку, що кількість студентів, бажаючих стати в майбутньому неврологами або нейрохірургами, зростає в процесі навчання на кафедрі з 1 до $5 \%$.

6. Великі можливості відкрила Університетська клініка ОДМУ, з відкриттям якої покращились можливості наблизити студента до практичної роботи. Цьому сприяє низка факторів, а саме:

- більшість лікарів Університетської клініки безпосередньо входять в штат кафедр ОДМУ, що дає можливістьорганізаційновпливатинаможливістьнаближення студентів безпосередньо до лікувального процесу;

- можливість використати ресурси Університетської клініки ОДМУ для більш якісного вивчення роботи лікаря при всебічному обстеженні та визначенні остаточного діагнозу на всіх етапах (від диспансеризації на рівні поліклініки, діагностичного обстеження 3 застосуванням сучасних методик генетичного консультування та визначення генетичного поліморфізму багатьох захворювань до лікування в умовах сучасного терапевтичного, хірургічного стаціонарів згідно з прийнятими протоколами).

7. Найбільш зацікавлені в навчанні неврології студенти мають можливість брати участь у роботі наукового студентського гуртка. Робота гуртка має мету не тільки дати досвід літературного пошуку та публічного виступу з реферативною доповіддю на конференції, але й більш якісно опанувати практичні навички майбутнього невролога під час чергування в неврологічному відділенні в якості помічника чергового лікаря. В подальшому студент доповідає на засіданні гуртка клінічний приклад, з яким він зустрівся на чергуванні, клінічний протокол тактики діагностики та лікування, та свої враження від випадку. 
Висновки. На кафедрі нейрохірургії і неврології ОДМУ створена система для напрацювання практичних навичок студентами в роботі з пацієнтами, яка допомагає вирішити проблеми покращення якості навчально-лікувального процесу на кафедрі, зокрема:

1. Підвищується мотивація вивчення предмета “Неврологія" студентами-іноземцями, які високо цінують можливість працювати безпосередньо з пацієнтом у процесі навчання.

2. Виявляс та допомагає тим студентам, які оберуть неврологію та нейрохірургію своєю фаховою спеціальністю.

3. Схема взаємодії (викладач кафедри - студент лікуючий лікар - пацієнт) дає можливість покращити якість засвоєння навчального матеріалу.
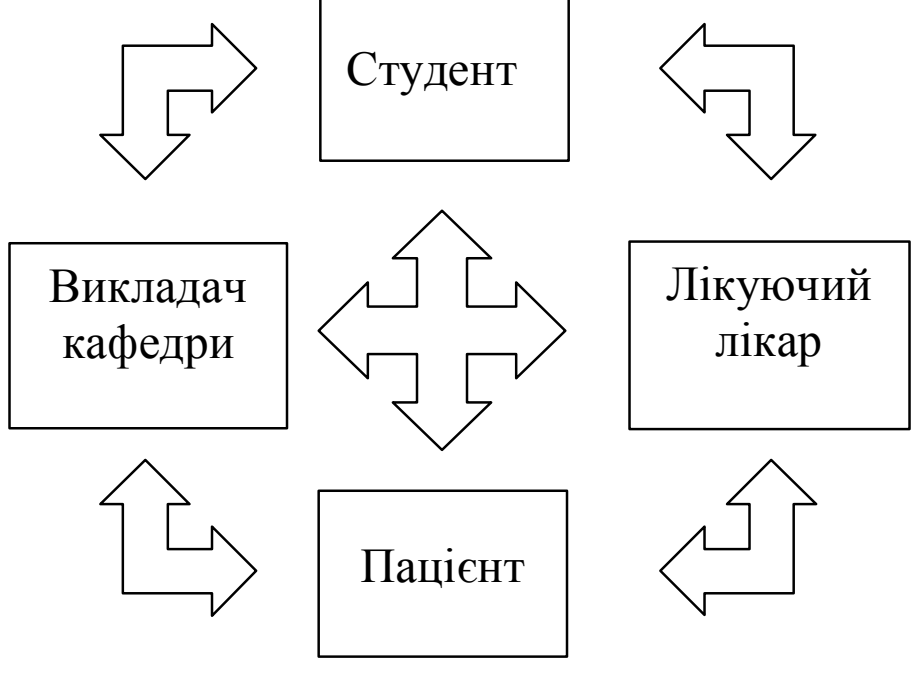

4. Освоєння історичних надбань одеської неврологічної школи підвищує авторитет Одеського державного медичного університету, його конкурентоспроможність, як провідного медичного ВНЗ Півдня України.

5. Молоді фахівці-неврологи випускники ОДМУ впевнено себе відчувають в перші роки самостійної роботи, навіть коли вони працюють на великій відстані від

\section{Література}

1. Деякі особливості індивідуальної та самостійної роботи студентів-іноземців під час викладання курсу нервових хвороб / А. С. Сон, В. В. Добровольський, Ю. І. Горанський [та ін.] // Медична освіта. - 2009. - № 4. - С. 25-28.

2. Власний досвід використання інформаційно-комуні-

провідних медичних центрів. Це обумовлено тісною співпрацею та взаємодовірливими відносинами між викладачами кафедри та студентами, які вибрали своїм майбутнім фахом неврологію. Згідно з опитуванням лікарів-неврологів, які проходять передатестаційні цикли на кафедрі нейрохірургії і неврології, $40 \%$ з них вибрали своє спеціалізацією неврологію завдяки мотиваційному впливу викладачів кафедри.

каційних технологій у самостійній роботі студентів під час викладання курсу нервових хвороб / А. С. Сон, В. В. Добровольський, Ю. І. Горанський [та ін.] // Медична освіта. 2009. - № 4. - C. 30-33. 